\title{
Japan optimistic on moves to resume commercial whaling
}

Tokyo. Japan's whaling fleet may emerge as both a winner and a loser in its fight to resume commercial whaling at next week's meeting of the International Whaling Commission (IWC) in Mexico.

After years of debate and scientific analysis, the plenary session of the IWC is expected to accept in principle a revised management procedure (RMP) that has been devised by the IWC scientific committee to allow resumed commercial whaling for the relatively abundant minke whale.

At the same time, however, there is a strong possibility that a French proposal to establish a sanctuary in the Southern Ocean will be accepted by the IWC, thus preventing Japan from whaling in the Antarctic, where its commercial whaling fleets used to operate. On a separate front, Japan is making a new move to win IWC approval to start research whaling for minke whales in the North Pacific.

The IWC introduced a moratorium on commercial whaling in 1986 , on the grounds that there was insufficient data on the size of whale populations and reproduction rates to know whether commercial whaling could be sustained.

By 1991, the commission's scientific committee had developed the RMP, and estimated the population of Antarctic minke whale at 760,000 , well above the number required to resume commercial whaling (see Nature 357, 532; 1992).

The representatives of most of the countries represented on the IWC were reluctant to adopt the RMP - and thus to lift the moratorium - because they feared it would be politically unacceptable at home. Instead, they asked the scientific committee to address further questions about the management procedure (see Nature 363, 9; 1993).

But the US administration of President Bill Clinton is now pressing for acceptance of the RMP in Mexico, and three leading environmental organizations - Greenpeace, the World Wide Fund for Nature, and the International Fund for Animal Welfare are not opposing this move.

The environmental groups fear that any further delays could lead to the break-up of the IWC, resulting in the whaling nations walking out to resume commercial activities. They will, however, press for stringent safeguards that will, if implemented, delay resumption of commercial whaling for several years.

Furthermore, there is a strong possibility that a French proposal to establish a whale sanctuary in the Antarctic will be adopted at the meeting. But this will not please the Japanese; Fukuzo Nagasaki, director- general of Japan's Institute of Cetacean Research says he is "pessimistic" about the vote on the sanctuary.

Whaling nations need the support of at least one quarter of the 30 or so IWC members attending at Mexico to block the sanctuary proposal. At present, however, Japan can only count on six or seven votes.

Nagasaki says that the critics of whaling have created a "double net" with their sanctuary proposal so that, even if the RMP is

\section{IMAGE UNAVAILABLE FOR COPYRIGHT REASONS}

\section{hale meat still on the menu.}

accepted and the moratorium is lifted, Japan will still be unable to resume commercial whaling in the Antarctic.

Japan has made a new move by suggesting to the IWC scientific committee prior to the plenary session that it should be allowed to catch 100 minke whales in the North Pacific for research purposes. Until now, Japan's research whaling has been confined to the Antarctic.

According to Nagasaki, the Antarctic research aims at determining population size and reproduction rates in minke whales. In contrast, research in the North Pacific will try to identify the precise size and distribution of breeding stocks of minke whales.

Such data, which will include DNA analysis of the whales, is critical for operation of the RMP, he says. If stock sizes are large, then the sustainable quota under the RMP is also large; but if the whales are split into small groups, the quotas may be too small to make commercial operations viable.

Nagasaki says the North Pacific proposal is not a strategy to get around the attempts of critics to block whaling in the Antarctic. But he says it is indirectly related to Japan's attempts to get IWC permission for small whaling communities in Japan to catch minke whale in the Pacific

The Royal Society for the Protection of Animals, one of the UK's leading animal welfare organizations, condemns the proposals to resume both scientific and commercial whaling - even on a small scale in protest at the methods currently used to kill whales.

David Swinbanks

\section{Weather satellite decision 'epitomizes new US strategy'}

Washington. US military and non-military weather satellite systems are to be combined in a move that officials of the Clinton administration claim will save the government $\$ 300$ million over the next five years, and up to $\$ 1.5$ billion after that.

The restructuring was announced last week by John Gibbons, the president's science and technology adviser, who said that it is being undertaken as part of Vice-President $\mathrm{Al}$ Gore's mission to "re-invent" government.

The move will combine existing polarorbiting weather satellite systems, at present operated separately by the Department of Defense and the Department of Commerce's National Oceanic and Atmospheric Administration (NOAA), into a single programme led by the latter. The National Aeronautics and Space Administration (NASA) will carry out research and development on future enhancements to the combined programme.

The administration also announced that it intends to proceed with the Landsat remote sensing programme by building Landsat 7 under another new interagency structure. Landsat 6 was lost on launch last year. NASA will take over the acquisition of the new programme from the Department of Defense, the commerce department will operate the satellite, and the US Geological Survey - part of the Department of the Interior - will run the archive storing Landsat data.

According to Gibbons, these moves reflect improved collaboration between government agencies under the new National Science and Technology Council (NSTC), which the president set up last autumn (see Nature 365, 195; 1993).

Under the executive order that covers the combined weather satellite programme, Defense, Commerce and NASA will establish an Integrated Program Office to run the new programme, which will consist of three satellites instead of the existing four (two civilian and two military).

The three agencies will pursue negotiations with the European Eumetsat weather satellite programme about incorporating a European satellite into the converged system. Officials say this could save even more money, but admit that the national security role of the new US programme may make collaboration more difficult. "National security is seen as absolutely supreme," one official said.

Vice-President Gore said in a statement that the move "epitomizes the spirit and potential of reinventing government". Gibbons said the merger now being achieved had been unsuccessfully attempted eight times in the past 20 years. Colin Macilwain 